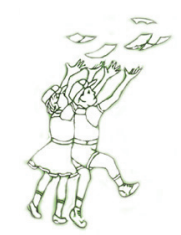

Wahana Sekolah Dasar

Tahun 26 Nomor 2 Juli 2018

Hlm 43-50

Tersedia Online di http://journal2.um.ac.id/index.php/wsd/

ISSN 0854-8293 (cetak) ISSN 2622-5883 (online)

\title{
PEMBELAJARAN MATEMATIKA MODEL GUIDED INQUIRY UNTUK MENINGKATKAN HASIL BELAJAR SISWA SEKOLAH DASAR
}

\author{
Kistin Restu Perdana, M. Zainuddin, Yuniawatika \\ PP3 Jl. Ir. Soekarno No.1 Blitar, Universitas Negeri Malang \\ e-mail:omokistin20@gmail.com
}

\begin{abstract}
Abstrak: Hasil belajar siswa kelas IV B SDN Ponggok 04 Kabupaten Blitar pada mata pelajaran matematika masih rendah dikarenakan tingkat pemahaman siswa terhadap konsep matematika masih kurang dan bersifat sementara. Salah satu solusi pemecahan masalah yang dapat dilakukan yaitu dengan menerapkan model guided inquiry pada pembelajaran matematika agar hasil belajar siswa dapat meningkat. Penelitian ini dilaksanakan dalam 2 siklus, dengan hasil rata-rata aktivitas guru dan siswa pada siklus I yaitu $84,5 \%$ dan $83,25 \%$ meningkat pada siklus 2 yaitu $96 \%$ dan $98 \%$. Sedangkan untuk rata-rata ketuntasan klasikal pada siklus I yaitu 50\%, dan meningkat pada siklus II sebesar $87,5 \%$.
\end{abstract}

Kata kunci: matematika, hasil belajar, guided inquiry

Proses pembelajaran di kelas bertujuan untuk mencapai suatu tujuan pendidikan yang diharapkan dan terciptanya pembelajaran yang berkualitas. Salah satu upaya yang dapat dilakukan guru untuk mewujudkan pembelajaran yang berkualitas adalah dengan memperbaiki sistem pembelajaran yang lebih inovatif, efektif, dan efisien. Pencapaian hasil belajar yang baik, khususnya dalam pembelajaran matematika begitu erat kaitannya dengan upaya untuk memahami matematika melalui pemecahan masalah yang konkret dan kontekstual. Dengan demikian proses pembelajaran matematika yang dilakukan guru akan lebih efektif dan siswa mudah memahami serta menerapkannya dalam kehidupan sehari-hari.

Pembelajaran matematika menuntut siswa untuk berpikir kritis guna memecahkan permasalahan sehari-hari. Hal ini sesuai pendapat Susanto (2013:16) menyatakan "pembelajaran matematika adalah suatu proses belajar mengajar yang dibangun oleh guru untuk mengembangkan kreativitas berpikir siswa yang dapat meningkatkan kemampuan berpikir siswa, serta dapat meningkatkan ke- mampuan mengkonstruksi pengetahuan baru sebagai upaya peningkatan penguasaan baik terhadap materi matematika". Lebih lanjut Heruman (2008:4) menyatakan bahwa pembelajaran matematika harus mampu mengaktifkan siswa selama proses pembelajaran, sehingga pembelajaran yang berlangsung menjadi suatu proses pembelajaran yang berpusat pada siswa dan bermakna bagi siswa.

Berdasarkan hasil observasi yang dilakukan pada tanggal 18 Januari 2017 di kelas IV B SDN Ponggok 04 diperoleh bahwa hasil belajar siswa kelas IV B pada pembelajaran matematika masih berada di bawah KKM, dengan persentase ketuntasan sebesar 30\%. Salah satu materi matematika yang belum dapat diserap dengan baik adalah pecahan. Terdapat permasalahan yang dialami guru dalam mengajar matematika yaitu guru jarang menggunakan media pembelajaran. Permasalahan yang mengakibatkan hasil belajar siswa rendah terutama pada materi pecahan yaitu pemahaman siswa terhadap materi pecahan yang masih bersifat sementara. Selain itu rata-rata kemampuan awal yang dimiliki siswa masih kurang sehingga siswa mengalami ke- 
sulitan dalam memahami materi selanjutnya termasuk materi pecahan ini.

Mengetahui adanya permasalahan kesulitan belajar siswa yang mengakibatkan hasil belajar siswa masih di bawah rata-rata, maka digunakan model guided inquiry sebagai salah satu model inovatif yang akan diterapkan pada pembelajaran matematika materi pecahan. Digunakannya model guided inquiry karena pembelajaran matematika yang bertujuan menciptakan individu yang dapat berpikir kritis dan aktif, sejalan dengan karakteristik model pembelajaran guided inquiry. Menurut Sagala (2010:24) inkuiri terbimbing (guided inquiry) merupakan bagian dari kegiatan pembelajaran dengan pendekatan kontekstual, pengetahuan, dan keterampilan yang diperoleh siswa diharapkan bukan hanya dari hasil mengingat fakta-fakta melainkan juga dari menemukan sendiri.

Penerapan model guided inquiry memiliki beberapa langkah (sintak) diantaranya (a) orientasi, (b) merumuskan masalah, (c) merumuskan hipotesis, (d) mengumpulkan data, (e) menguji hipotesis, dan (f) merumuskan kesimpulan. Model guided inquiry mendorong siswa untuk berpikir sendiri, menganalisis sendiri, dan aktif sehingga dapat menemukan prinsip umum berdasarkan bahan atau data yang telah disediakan guru. Pemahaman siswa terhadap suatu konsep akan lebih bermakna jika siswa mencari sendiri konsep tersebut. Tidak lepas dari hal itu, guru sebagai fasilitator harus tetap membimbing dan memberikan arahan sampai siswa dapat menemukan apa yang ingin diketahuinya melalui suatu proses pembelajaran matematika yang bermakna.

Pembelajaran dengan menerapkan model guided inquiry diharapkan dapat meningkatkan pemahaman dan kemampuan berpikir kritis siswa. Selain itu, dapat mengembangkan daya nalar siswa karena model pembelajaran ini memberikan kesempatan kepada siswa untuk aktif membangun pengetahuan khususnya pelajaran matematika. Penggunaan model guided inquiry sangat dimungkinkan hasil belajar siswa dapat meningkat.
Berdasarkan uraian tersebut masalah dalam penelitian ini adalah rendahnya hasil belajar siswa pada pembelajaran matematika materi pecahan. Tujuan penelitian adalah (1) mendeskripsikan penerapan model guided inquiry pada pembelajaran matematika di kelas IV B SDN Ponggok 04 Kabupaten Blitar, (2) mendeskripsikan peningkatan hasil belajar siswa dengan model guided inquiry pada pembelajaran matematika kelas IV B SDN Ponggok 04 Kabupaten Blitar.

\section{METODE}

Penelitian ini merupakan penelitian deskriptif kualitatif yang menerapkan pembelajaran matematika dengan model guided inquiry untuk meningkatkan hasil belajar siswa. Penelitian ini menggunakan jenis penelitian tindakan kelas (PTK) atau Classroom Action Research (CAR). Menurut Kusumah (2010:9) "Penelitian Tindakan Kelas (PTK) adalah penelitian yang dilakukan oleh guru di kelasnya sendiri dengan cara (1) merencanakan, (2) melaksanakan, (3) merefleksikan tindakan secara kolaboratif dan partisipatif dengan tujuan memperbaiki kinerjanya sebagai guru, sehingga hasil belajar siswa dapat meningkat". Dalam penelitian ini terdapat tahapan-tahapan sesuai dengan pendapat Kemmis dan M. C. Taggart (dalam Wiriatmadja, 2014:66) yang mana dalam setiap siklus terdiri dari perencanaan, tindakan, pengamatan, dan refleksi.

Pelaksanaan penelitian menggunakan 2 siklus yang dilaksanakan pada semester dua tahun ajaran 2016/2017 di kelas IV B SDN Ponggok 04 Kabupaten Blitar dengan subjek penelitian guru dan siswa. Peran peneliti dalam penelitian ini adalah sebagai perencana, pelaksana, pengamat, pengumpul, dan penganalisis data serta pelapor hasil penelitian.

Data dalam penelitian ini berupa data aktivitas guru dan siswa serta data hasil belajar siswa yang diperoleh melalui tes. Sumber data yaitu guru dan siswa. Kelas IV B SDN Ponggok 04 Kabupaten Blitar berjumlah 20 siswa, yang terdiri dari 13 siswa dan 7 siswi. 
Penelitian dilakukan selama 4 minggu dimulai dari tanggal 5 Maret 2017 s.d. 27 Maret 2017.

Pengumpulan data yang digunakan yaitu observasi, wawancara, dokumentasi, tes, dan catatan lapangan. Sedangkan untuk instrumen penelitian guna memperoleh data yaitu lembar observasi aktivitas guru dan siswa, serta lembar tes evaluasi yang diberikan pada setiap akhir pertemuan.

Analisis data dalam penelitian ini dilakukan melalui 3 tahapan yaitu reduksi data, penyajian data, dan penarikan kesimpulan. Reduksi data dilakukan dengan cara menyeleksi, memfokuskan, dan menyederhanakan semua data yang diperoleh. Pada tahap ini aktivitas guru dan siswa dianalisis dan hasil analisis disesuaikan dengan taraf keberhasilan sebagai berikut.

\section{Tabel 1. Pedoman Predikat Penilaian}

\begin{tabular}{|c|c|c|}
\hline Rentang Nilai & Predikat & Kriteria \\
\hline $86-100$ & A & Sangat Baik \\
$71-85$ & B & Baik \\
$56-70$ & C & Cukup \\
$<55$ & D & Perlu Bimbingan \\
\hline
\end{tabular}

Data hasil belajar siswa diperoleh dari LKS dan hasil tes evaluasi. Penilaian yang dilakukan meliputi aspek sikap, pengetahuan, dan keterampilan. Penilaian sikap diambil dari sikap yang sering muncul atau dominan. Pengolahan nilai pengetahuan siswa dilakukan dengan cara berikut.

$$
\text { Nilai Pengetahuan }=\frac{\text { Nilai } L K S+\text { Nilai Tes Evaluasi }}{2}
$$

Ketuntasan belajar klasikal merupakan penguasaan penuh hasil yang didapat oleh siswa dalam menguasai materi tertentu secara menyeluruh yang dibuktikan dengan hasil belajar yang baik pada materi tertentu. Dalam menghitung persentase ketuntasan belajar klasikal digunakan rumus.

Ketuntasan Belajar Klasikal $=\frac{\sum \text { siswa yang tuntas belajar }}{\sum \text { siswa }} \times 100 \%$

Siswa dikategorikan tuntas apabila dapat mencapai skor minimal 70. Sedangkan untuk nilai keterampilan diambil dari capaian tertinggi yang diperoleh siswa.
Hasil analisis dijabarkan dalam tahap pemaparan data dan disajikan. Paparan disampaikan secara berurutan dari pratindakan, siklus I, dan siklus II. Paparan data ini digunakan sebagai dasar untuk melakukan penarikan kesimpulan dan keputusan dalam mengambil suatu tindakan.

\section{HASIL}

Data hasil penelitian pada pelaksanaan pembelajaran matematika materi pecahan dengan menggunakan model guided inquiry, aktivitas guru dan siswa mengalami peningkatan. Rekapitulasi hasil observasi aktivitas guru dan siswa siklus I dan II pada tabel 2.

Berdasarkan tabel 2 dapat dilihat dari pencapaian aktivitas guru pada siklus I pertemuan 1 aktivitas guru mencapai $81 \%$ kategori baik dan meningkat menjadi $88 \%$ kategori sangat baik pada pertemuan 2 . Sementara pencapaian aktivitas siswa di siklus I pada pertemuan 1 sebesar 79\% kategori baik, dan mengalami peningkatan pada pertemuan 2 menjadi 87,5\% kategori sangat baik. Pada siklus II terlihat dari aktivitas guru pada pertemuan 1 sebesar 92\% kategori sangat baik dan meningkat menjadi $100 \%$ pada pertemuan 2. Sementara aktivitas siswa pada siklus II sebesar $96 \%$ pada pertemuan 1 dan meningkat pada pertemuan 2 sebesar $100 \%$.

Temuan yang muncul berkaitan aktivitas guru dan siswa selama siklus I sampai siklus II yaitu (1) aktivitas guru masih kurang maksimal pada pelaksanaan siklus I hal ini dikarenakan beberapa kegiatan di dalam RPP belum terlaksana, namun pada siklus II aktivitas guru mengalami peningkatan, (2) siswa masih belum terbiasa mengikuti pembelajaran dengan menggunakan model guided inquiry.

Kegiatan pembelajaran pada siklus I dan II menerapkan model guided inquiry dengan penilaian hasil belajar siswa yang mecakup ranah sikap, pengetahuan dan keterampilan. Rekapitulasi penilaian pengetahuan yang digunakan sebagi indikator peningkatan siklus I dan II dapat dilihat pada tabel 3. 
Tabel 2. Rekapitulasi Hasil Observasi Aktivitas Guru dan Siswa

\begin{tabular}{llcccc}
\hline & Aspek & \multicolumn{2}{c}{ Siklus I } & \multicolumn{2}{c}{ Siklus II } \\
\cline { 3 - 6 } & P1 & P2 & P1 & P2 & \\
\hline Aktivitas & Pencapaian (\%) & 81 & 88 & 92 & 100 \\
Guru & Kategori & Baik & Sangat Baik & Sangat Baik & Sangat Baik \\
Aktivitas & Pencapaian (\%) & 79 & 87,5 & & 96 \\
Siswa & Kategori & Baik & Sangat baik & Sangat Baik & Sangat Baik \\
\hline
\end{tabular}

Tabel 3. Rekapitulasi Hasil Belajar Siswa

\begin{tabular}{|c|c|c|c|c|c|c|c|c|c|c|}
\hline & \multirow{3}{*}{$\begin{array}{c}\begin{array}{c}\text { Pra } \\
\text { tindakan }\end{array} \\
\text { Nilai } \\
\end{array}$} & & \multicolumn{4}{|c|}{ Siklus I } & \multicolumn{4}{|c|}{ Siklus II } \\
\hline & & \multicolumn{2}{|c|}{ P1 } & \multicolumn{2}{|r|}{$\mathbf{P 2}$} & \multicolumn{2}{|c|}{ P1 } & \multicolumn{2}{|c|}{ P2 } & \multirow[b]{2}{*}{$\mathbf{T}$} \\
\hline & & $\mathbf{T}$ & Nilai & $\mathbf{T}$ & Nilai & $\mathbf{T}$ & Nilai & $\mathbf{T}$ & Nilai & \\
\hline Jumlah & 1201 & 6 & 1309 & 8 & 1463,5 & 12 & 1565 & 15 & 1815 & 20 \\
\hline Rata-rata & 60,5 & - & 65,5 & - & 73,2 & - & 78,3 & - & 90,8 & - \\
\hline Persentase & \multicolumn{2}{|c|}{$30 \%$} & \multicolumn{2}{|c|}{$40 \%$} & \multicolumn{2}{|c|}{$60 \%$} & \multicolumn{2}{|c|}{$75 \%$} & \multicolumn{2}{|c|}{$100 \%$} \\
\hline Kategori & \multicolumn{2}{|c|}{ Perlu Bimbingan } & \multicolumn{2}{|c|}{$\begin{array}{c}\text { Perlu } \\
\text { Bimbingan }\end{array}$} & \multicolumn{2}{|c|}{ Cukup } & \multicolumn{2}{|c|}{ Baik } & \multicolumn{2}{|c|}{ Sangat Baik } \\
\hline
\end{tabular}

Keterangan: $\mathrm{T}=$ Tuntas

Berdasarkan tabel 3 terlihat pada siklus I pertemuan pertama, rata-rata hasil belajar siswa adalah 65,5 dengan persentase ketuntasan klasikal sebesar 40\% kriteria perlu bimbingan. Berdasarkan jumlah seluruh siswa IV B sebanyak 20 anak, hanya 8 siswa yang tuntas. Pada pertemua kedua rata-rata hasil belajar siswa adalah 73,2 dengan persentase ketutasan klasikal sebesar $60 \%$ kriteria cukup. Siswa yang tuntas pada pertemuan kedua ini sebanyak 12 siswa. Terjadi peningkatan hasil belajar tahap pratindakan ke tahap siklus I meskipun ketuntasan klasikal belum mencapai ketuntasan yang diharapkan yaitu $75 \%$.

Hasil belajar siswa pada siklus I masih belum mencapai ketuntasan belajar klasikal yakni 75\%, maka dilaksanakan siklus II dengan rencana perbaikan berdasarkan hasil refleksi siklus I. Pada siklus II pertemuan pertama diperoleh rata-rata hasil belajar siswa adalah 78,3 dengan persentase ketuntasan klasikal 75\% kriteria baik. Terdapat 15 siswa dari 20 siswa yang tuntas dalam pembelajara pertemuan pertama. Sementara pada pertemuan kedua, rata-rata hasil belajar siswa adalah 90,8 dengan persentase ketuntasan
100\% kriteria sangat baik. Dalam pembelajaran pertemuan kedua ini seluruh siswa tuntas. Jadi, penerapan model guided inquiry dengan benar pada pembelajaran matematika dapat meningkatkan aktivitas guru dan siswa serta meningkatkan hasil belajar siswa. Selain itu berdasarkaan hasil tersebut penelitian berhenti pada siklus II.

Selama pelaksanaan pembelajaran pada pratindakan, siklus I, dan II diperoleh temuan berkaitan dengan hasil belajar siswa yaitu (1) perubahan sikap yang meliputi aspek percaya diri dan bertanggung jawab mengalami peningkatan, (2) hasil belajar ranah pengetahuan juga mengalami peningkatan mencapai $100 \%$ di akhir siklus, (3) penggunaan media pembelajaran dapat meningkatkan kemampuan dan minat belajar anak, hal ini dibuktikan dengan meningkatnya keterampilan penggunaan media setiap siswa.

\section{PEMBAHASAN}

Penerapan model guided inquiry pada pembelajaran matematika materi pecahan di kelas IV B SDN Ponggok 04 Kabupaten Blitar dilakukan selama dua siklus. Hasil observasi 
aktivitas guru dalam menerapkan model guided inquiry pada siklus I pertemuan 1 mencapai $81 \%$ dengan kategori baik. Aktivitas guru yang belum muncul pada pertemuan ini yaitu guru belum mempersiapkan siswa untuk belajar, guru belum memberikan tanggapan terhadap pendapat siswa, guru belum membimbing siswa dalam membuat pertanyaan, menjelaskan langkah kerja dan melakukan refleksi pembelajaran. Pada pertemuan kedua aktifitas guru meningkat menjadi 88\% dengan kategori sangat baik. Aktivitas guru yang belum muncul pada pertemuan ini yaitu mengondisikan siswa siap untuk belajar dan menjalankan langkah kerja.

Persentase aktivitas siswa pada siklus I pertemuan 1 sebesar 79\% dengan kategori baik. Aspek yang belum muncul yaitu persiapan sebelum belajar, menanggapi orientasi masalah, menggunakan sumber belajar lain, menanggapi pendapat kelompok lain dan menanyakan materi yang belum dipahami. Hal ini belum muncul dikarenakan siswa masih belum terbiasa dengan pembelajaran dengan menerapakan model guided inquiry, selain itu rasa percaya diri anak masih belum berkembang. Pada pertemuan kedua, aktivitas siswa mengalami peningkatan menjadi $87,5 \%$ kategori sangat baik.

Persentase aktivitas guru pada siklus II pertemuan 1 sebesar 96\% dengan kategori sangat baik dan meningkat pada pertemuan 2 sebesar 100\% dengan kategori dangat baik. Penyebab aktivitas guru terus meningkat hingga mencapai skor maksimal yaitu guru selalu melakukan pembelajaran dengan memperhatikan dan mempelajari betul langkahlangkah yang harus dilakukan sesuai dengan perencanaan pembelajaran dengan menerapkan model guided inquiry. Selain itu, guru selalu melakukan refleksi dan evaluasi guna persiapan pembelajaran selanjutnya.

Sedangkan untuk persentase aktivitas siswa pada siklus II pertemuan 1 sebesar $96 \%$ kategori sangat baik dan meningkat pada pertemuan 2 sebesar $100 \%$. Hal ini menandakan seluruh siswa dapat mengikuti pembelajaran sesuai dengan langkah model guided inquiry. Berikut grafik penerapan model guided inquiry oleh guru dan siswa dari siklus I sampai siklus II.

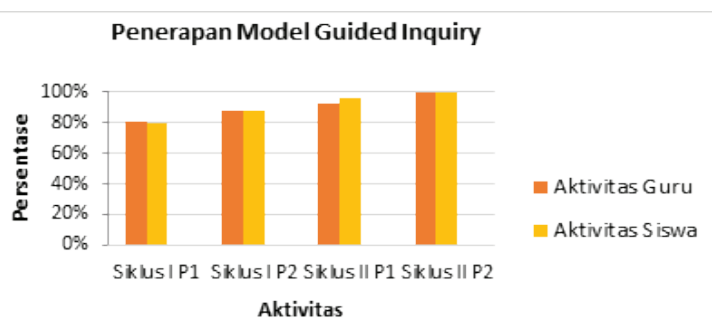

\section{Gambar 1. Grafik Rekapitulasi Penerapan Model Guided Inquiry}

Berdasarkan gambar grafik 1 dapat dilihat bahwa pelaksanaan pembelajaran dengan menerapkan model guided inquiry yang dilakukan oleh guru dan siswa sudanh sangat baik dan selalu mengalami peningkatan pada setiap pertemuan. Penerapan model guided inquiry pada pembelajaran matematika materi pecahan sudah dilaksanakan dengan baik. Guru melaksanakan pembelajaran menggunakan RPP yang disusun sesuai dengan langkahlangkah model guided inquiry. Langkah-langkah model guided inquiry menurut Sanjaya (2009:202) adalah (1) orientasi, (2) merumuskan masalah, (3) merumuskan hipotesis, (4) mengumpulkan data, (5) menguji hipotesis, (6) merumuskan kesimpulan.

Model pembelajaran guided inquiry dipilih diterapkan pada pembelajaran matematika di kelas IV B SDN Ponggok 04 karena model tersebut belum pernah diterapkan dan juga model ini sesuai dengan karakteristik pembelajaran matematika. Heruman (2008:4) menyatakan bahwa pembelajaran matematika harus mampu mengaktifkan siswa selama proses pembelajaran, sehingga pembelajaran yang berlangsung menjadi suatu proses pembelajaran yang berpusat pada siswa dan bermakna bagi siswa. Hal ini selaras dengan karakteristik pembelajaran inkuiri menurut Sanjaya (2009:196) karakteristik pembelajaran inkuiri yakni (a) menekankan aktivitas kepada siswa untuk mencari dan menemu- 
kan jawaban sendiri, dan (b) memiliki tujuan mengembangkan kemampuan berpikir secara sistematis, logis, dan kritis.

Penerapan model guided inquiry pada pembelajaran matematika di kelas IV B SDN Ponggok 04 memberikan perubahan yang baik terhadap aktivitas siswa selama mengikuti pembelajaran. Temuan yang diperoleh yaitu siswa lebih aktif ketika pembelajaran berlangsung pada sintak pengumpulan data. Siswa terlihat lebih aktif karena terlibat langsung menyelidiki dan menggunakan media guna menemukan konsep-konsep materi pelajaran. Hal ini sesuai dengan pendapat Hanifah dan Suhana (2010:78) bahwa pembelajaran dengan menggunakan model guided inquiry dapat membangkitkan motivasi dan gairah belajar peserta didik untuk belajar lebih giat lagi.

Temuan lain yang diperoleh dengan diterapkannya model guided inquiry yaitu terdapat tiga siswa yang biasanya tidak pernah mau mengikuti pembelajaran, tapi tiga siswa tersebut antusias dan tertarik mengikuti pembelajaran dengan menerapkan model guided inquiry. Ketiga siswa tersebut tampak antusias ketika melakukan kegiatan pengumpulan data dengan secara langsung berinteraksi dengan media pembelajaran. Hal ini sesuai dengan kelebihan model guided inquiry menurut Hanifah dan Suhana (2010:78) yang berpendapat bahwa pembelajaran menggunakan model guided inquiry dapat membantu peserta didik untuk mengembangkan kesiapan serta penguasaan keterampilan dalam proses kognitif.

Permasalahan umum yang muncul pada pembelajaranantaralainpenelitiyangbertindak sebagai guru belum dapat mengondisikan dan melakukan pemusatan perhatian siswa dengan baik sehingga pembelajaran kurang kondusif. Masih terjadi kegaduhan ketika pembagian kelompok dilakukan pada saat pembelajaran dimulai. Siswa masih belum terbiasa dengan pembelajaran menggunakan model guided inquiry, sehingga siswa masih sering bertanya terkait langkah kegiatan yang dilakukan.
Permasalahan tersebut dapat teratasi pada pelaksanaan siklus II.

Hasil belajar siswa pada pembelajaran matematika melalui model guided inquiry di kelas IV B SDN Ponggok 04 dapat meningkat. Hasil belajar siswa yang mengalami peningkatan meliputi aspek sikap, pengetahuan, dan keterampilan. Peningkatan ini terjadi dimulai dari tahap pratindakan, siklus I, hingga siklus II. Hal ini sesuai dengan pendapat Hamalik (dalam Ekawarna, 2013:70) bahwa hasil belajar adalah perubahan tingkah laku pada diri siswa yang dapat diamati dan diukur dalam bentuk perubahan pengetahuan, sikap, dan keterampilan. Oleh sebab itu, selama penelitian telah dilakukan pengamatan dan pengukuran terkait proses pembelajaran dan hasil belajar siswa. Berikut pembahasan mengenai hasil belajar tahap pratindakan, siklus I, dan siklus II.

Penilaian sikap yang dikembangkan dalam penelitian ini adalah sikap percaya diri dan tanggung jawab. Terjadi peningkatan secara bertahap untuk kedua sikap tersebut mulai dari sklus I hingga siklus II. Pada pembelajaran siklus I pertemuan pertama dan kedua, diketahui bahwa sikap percaya diri pada siswa masih kurang. Sedangkan sikap tanggung jawab dapat dikatakann cukup, hal ini dikarenakan siswa dapat mengerjakan semua tugas dengan penuh tanggung jawab namun hanya ada sebagian kecil siswa yang belum dapat mengerjakan tugas dengan penuh tanggung jawab. Sementara pada siklus II pertemuan pertama dan kedua, perubahan sikap semakin terlihat meningkat baik sikap percaya diri maupun tanggung jawab.

Hasil belajar ranah pengetahuan yang dikembangkan pada penelitian ini yaitu penguasaan materi pecahan yang diperoleh melalui pengolahan nilai LKS dan tes evaluasi pada setiap pertemuan. Hasil belajar siswa yang diperoleh dalam tahap pratindakan hanya terbatas pada ranah pengetahuan dengan rata-rata kelas yaitu 60,5 . Jumlah siswa yang tuntas pada tahap tahap ini yaitu 6 siswa dan 14 siswa 
belum mencapai KKM atau bisa dikatakan belum tuntas. Sedangkan untuk persentase ketuntasan klasikal sebesar 30\% dengan kriteria perlu bimbingan dan belum mencapai standar ketuntasan belajar klasikal. Ketuntasan belajar siswa ditentukan oleh masing-masing sekolah yang dikenal dengan istilah kriteria ketuntasan minimal (KKM). Karena ketuntasan belajar klasikal masih rendah, maka dilakukan perbaikan pelaksanaan pembelajaran matematika menggunakan model pembelajaran guided inquiry pada siklus I dan siklus II.

Siklus I pertemuan pertama, rata-rata hasil belajar siswa adalah 65,5 dengan persentase ketuntasan klasikal sebesar 40\% kriteria perlu bimbingan. Dari jumlah seluruh siswa IV B sebanyak 20 anak, hanya 8 siswa yang tuntas. Pada pertemua kedua rata-rata hasil belajar siswa adalah 73,2 dengan persentase ketutasan klasikal sebesar $60 \%$ kriteria cukup. Siswa yang tuntas pada pertemuan kedua ini sebanyak 12 siswa. Berdasarkan pembahasan tersebut, dapat dikatakan adalanya peningkatan hasil belajar tahap pratindakan ke tahap siklus I meskipun ketuntasan klasikal belum mencapai ketuntasan yang diharapkan yaitu $75 \%$.

Karena hasil belajar siswa pada siklus I masih belum mencapai ketuntasan belajar klasikal yakni 75\%, maka dilaksanakan siklus II dengan rencana perbaikan berdasarkan hasil refleksi siklus I. Pada siklus II pertemuan pertama diperoleh rata-rata hasil belajar siswa adalah 78,3 dengan persentase ketuntasan klasikal 75\% kriteria baik. Terdapat 15 siswa dari 20 siswa yang tuntas dalam pembelajara pertemuan pertama. Sementara pada pertemuan kedua, rata-rata hasil belajar siswa adalah 90,8 dengan persentase ketuntasan $100 \%$ kriteria sangat baik. Dalam pembelajaran pertemuan kedua ini seluruh siswa tuntas. Peningkatan nilai rata-rata dan ketuntasan klasikal hasil belajar siswa ranah pengetahuan ditunjukkan oleh gambar grafik berikut.

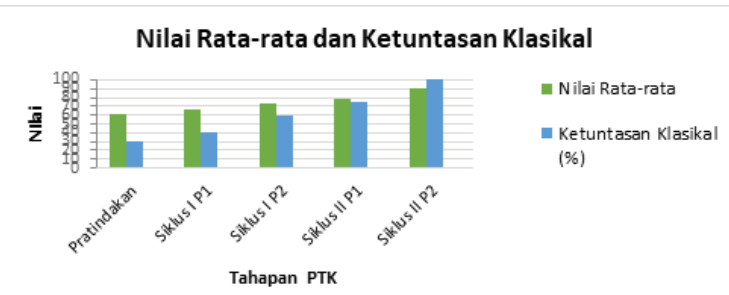

Gambar 2. Grafik Rekapitulasi Nilai Rata-rata dan Ketuntasan Klasikal

Penilaian keterampilan dilakukan saat kegiatan pembelajaran berlangsung. Aspek keterampilan yang dinilai yaitu penggunaan media pembelajaran dan menyampaikan hasil diskusi. Pada siklus I, pertemuan pertama dan kedua diperoleh hasil penggunaan media dengan nilai tertinggi yang dilakukan siswa hanya mencapai keriteria baik pada interval nilai 71-85. Penggunaan media sangat penting dalam pembelajaran matematika yang cendrung menekankan pada suatu hal yang konkret. Menurut Sumiati dan Asra (2007:160) menyatakan bahwa "bentuk-bentuk media pembelajaran sangan membantu peningkatan pengalaman belajar agak menjadi lebih konkret". Sedangkan kemampuan menyampaikan pendapat bergantung pada sikap percaya diri yang dimiliki siswa. Ketercapaian nilai maksimal aspek menyampaikan pendapat hanya mencapai ketagori baik dengan interval nilai 71-85.

Peningkatanhasilnilaiketerampilan terjadi pada siklus II pertemuan pertama dan kedua. Pada pertemuan pertama, jenis keterampilan penggunaan media dan menyampaikan hasil diskusi mengalami peningkatan dari siklus I. Ketercapaian tertinggi nilai keterampilan mencapai kategori sangat baik dengan interval nilai 86-100. Sementara pertemuan kedua juga mengalami peningkatan hasil penilaian keterampilan, capaian nilai tertinggi pada kategori sangat baik dengan interval nilai 86100.

Berdasarkan pembahasan tersebut, dapat dikatakan bahwa ada peningkatan hasil belajar siswa yang terkait erat dengan penerapan 
model guided inquiry. Hal tersebut sesuai dengan pendapat Hanifa dan Suhana (2010:78) tentang kelebihan model guided inquiry yaitu membantu siswa untuk mengembangkan ksiapan serta keterampilan dalam proses kognitif. Nilai hasil belajar siswa pada siklus II sudah mencapai ketuntasan belajar klasikal yang ditentukan. Sementara itu dengan meningkatnya aktivitas dan hasil belajar ini sesuai dengan penelitian yang dilakukan oleh Effendi dkk (2014) pada siswa kelas VI SDN 12 Matan Hilir Utara diperoleh hasil bahwa digunakannya model pembelajaran guided inquiry dalam mata pelajaran matematika dapat meningkatkan hasil belajar siswa.

Dengan demikian, terbukti bahwa penerapan model guided inquiry pada pembelajaran matematika materi pecahan dilaksanakan dengan baik oleh guru dan siswa dapat meningkatkan hasil belajar siswa kelas IV B SDN Ponggok 04 Kabupaten Blitar.

\section{SIMPULAN DAN SARAN}

Berdasarkan hasil penelitian dan pembahasan dapat disimpulkan bahwa, (1) Penerapan model pembelajaran guided inquiry pada pembelajaran matematika dapat dilaksanakan guru dan siswa dengan sangat baik, sehingga meningkatan aktivitas guru dan aktifitas siswa. Hal ini dibuktikan dengan meningkatnya persentase pecapaian aktivitas guru dan siswa pada siklus I dan II. (2) Penerapan model pembelajaran guided inquiry pada pembelajaran matematika materi pecahan juga meningkatkan hasil belajar siswa di kelas IV B SDN Ponggok 04 Kabupaten Blitar.

Berdasarkan hasil temuan selama pelaksanaan penelitian saran-saran yang dapat diajukan sebagai berikut: (1) Bagi peneliti, diharapkan dapat mengembangkan kemampuan pedagogik. (2) Bagi siswa, dapat mengembangkan keterampilan dan sikap yang baik. (3) Bagi guru, diharapkan melakukan persiapan yang baik sebelum menerapkan model guided inquiry ataupun model inovatif yang lain dan menggunakan media pembelajaran yang sesuai materi pembelajaran, serta (3) Bagi sekolah, hendaknya menyediakan fasilitas pembelajaran yang memadai.

\section{DAFTAR RUJUKAN}

Effendi, dkk. 2014. Peningkatan Hasil Belajar Matematika dengan Metode Inkuiri Terbimbing di Kelas VI SDN 12 Matan Hilir Utara. Jurnal Pendidikan dan Pembelajaran, (Online), 3 (2014), (http:// jurnal.untan.ac.id/index.php/jpdpb/ article/view/4944), diakses 11 Januari 2017

Ekawarna. 2013. Penelitian Tindakan kelas. Jakarta selatan: Referensi (GP press Group)

Hanifah, S. \& Suhana, C. 2010. Konsep Strategi Pembelajaran. Bandung: Remaja Rosdakarya.

Heruman. 2010. Model Pembelajaran Matematika di Sekolah Dasar. Bandung: PT Remaja Rosdakarya.

Kusumah, Wijaya dan Dedi. 2010. Mengenal Penelitian Tindakan Kelas. Jakarta : PT Indeks

Sagala, S. 2010. Konsep dan Makna Pembelajaran. Bandung: Alfabeta.

Sanjaya, Wina. 2009. Penelitian Tindakan Kelas. Jakarta : Kencana

Sumiati \& Asra. 2007. Metode Pembelajaran. Bandung: CV Wacana Prima.

Susanto, A. 2013. Teori Belajar \& Pembelajaran di Sekolah Dasar. Jakarta: Prenadamedia Group

Wijaya, K. \& Dedi, D. 2010. Mengenal Penelitian Tindakan Kelas. Jakarta: PT Indeks

Wiriaatmadja, R. 2014. Metode Penelitian Tindakan Kelas untuk Meningkatkan Kinerja Guru dan Dosen. Bandung: Remaja Rosdakarya. 